\title{
RACE, GENDER, AND THE REBIRTH OF TRADE UNIONISM
}

\author{
Kate Bronfenbrenner \\ Cornell University \\ Dorian T. Warren \\ Columbia University
}

The future of the U.S. labor movement hinges on unions' ability to organize workers of color, women, and most especially, women of color. The majority of existing union members, and for at least the last two decades, the majority of new workers organized, are women and workers of color. Yet, with the exception of just a handful of unions, the labor movement has been slow to realize that its survival and revitalization is fundamentally intertwined with unions' ability to recognize and build on this trend.

African-American workers have historically been and continue to be the most pro-union and the most likely demographic group to be union members even though the decline in union density since the 1980 s has been the sharpest among black workers. While more than one in four African-American workers (27.1 percent) were union members in 1983, by 2006, this percentage had fallen to 14.5 percent. ${ }^{1}$ This nearly 13 percentage point drop contrasts with a 7 percentage point drop in density among white workers, and a 7 percentage point drop among Hispanic workers. Yet, as shown in Table 1, focusing solely on the changes in union density by race, without further bifurcating the data by gender, fails to capture the very different patterns occurring across both race and gender. Without question, the density loss has been much heavier among men then women, particularly among men of color, dropping 16 percentage points for black men, 14 points for Hispanic men, and 10 points for white men, compared to a drop in density for white and Hispanic women during this same twenty-three-year period of 5 percentage points or less. The drop in density was higher for black women (9 percentage points), but still much less than their male counterparts, and, in 2005, union density actually increased for African American women from 13.5 percent to 14.2 percent in one year, only to drop back down to 13.5 percent in $2006 .^{2}$

This significant decline in union density among workers of color has been overlooked in most discussions of the crisis facing the labor movement. The heavier job losses among black workers are due to the continued hemorrhaging of heavily unionized manufacturing jobs, the deunionization and downgrading of building, food, and home care services, and the adverse effects of privatization of the 
public sector, the occupations where many black workers had been concentrated since World War II ${ }^{3}$. In 2004 alone, over 400,000 manufacturing jobs left the United States, 39 percent of which were

\section{TABLE I}

Change in Union Density from 1983-2006

by Race and Gender

\begin{tabular}{|c|c|c|c|c|}
\hline \multicolumn{5}{|c|}{ Women } \\
\hline & Black & White & Hispanic & All \\
\hline 1983 & $22.6 \%$ & $13.3 \%$ & $16.5 \%$ & $14.6 \%$ \\
\hline 2006 & $13.5 \%$ & $10.6 \%$ & $9.7 \%$ & $10.9 \%$ \\
\hline \multicolumn{5}{|c|}{ Men } \\
\hline & Black & White & Hispanic & All \\
\hline 1983 & $31.6 \%$ & $24.1 \%$ & $24.1 \%$ & $24.7 \%$ \\
\hline 2006 & $15.6 \%$ & $13.5 \%$ & $9.8 \%$ & $13.0 \%$ \\
\hline \multicolumn{5}{|c|}{ Overall } \\
\hline & Black & White & Hispanic & All \\
\hline 1983 & $27.1 \%$ & $19.2 \%$ & $21.0 \%$ & $12.5 \%$ \\
\hline 2006 & $14.5 \%$ & $12.1 \%$ & $13.5 \%$ & $10.6 \%$ \\
\hline
\end{tabular}

Schmitt and Zipperer 2007

unionized and disproportionately located in the Midwest and Southeast regions. While black workers hit hardest by these productions shifts, and those most likely to lose union jobs, were concentrated in states such as Illinois, Michigan, and Ohio, both organized and unorganized African-American workers also lost jobs in the textile and furniture industries in states like North Carolina, where 160,000 workers lost their jobs between 2001 and 2004 alone. ${ }^{4}$ Replacing this massive disappearance of good union jobs have been low-wage, nonunion jobs in the service sector, creating what Steven Pitts calls the twodimensional crisis of work in black communities: unemployment and bad jobs. ${ }^{5}$

But the crisis of bad jobs is not limited only to African-American workers; other workers of color, including the overwhelming majority of immigrants and female workers, are also disproportionately concentrated in low-wage industries. They know that the best strategy for transforming bad jobs into good ones is unionization. Towards this end, workers of color, and especially black men and women, are organizing and organizing successfully at disproportionate rates, even though these workers have been 
the hardest hit by manufacturing job losses and the downsizing of the public sector. Yet, many in the labor movement have either ignored or downplayed the role of race and gender in organizing, and consequently have sidestepped the implications of increased numbers of workers of color and women for unions' organizing strategies, institutional practices, and political involvement. The labor movement is the largest mass membership organization of women, African Americans, Latinos, and Asians in the country (larger than the NAACP, NOW, La Raza, and LULAC combined). As such, the labor movement must not only pay much greater attention to organizing workers of color and women, but also think through what it means to represent these workers' interests and concerns internally, at the bargaining table, and in politics.

\section{THE CHALLENGE FOR ORGANIZING}

Data on NLRB union elections from the early part of this decade shows that women, and especially women of color, have the highest election win rates among all demographic groups. For example, units with a majority of white men have the lowest win rates (35 percent) compared to units that are majority workers of color (53 percent), majority women (58 percent), and especially units that are majority women of color ( 82 percent).${ }^{6}$ This is despite the fact that the majority of private sector organizing campaigns still occurs in occupations where women and people of color are the minority. And organizing outside of the broken and unfair NLRB process continues to increase, and with some significant successes involving workers of color. Recent non-Board and public sector campaign victories include the 49,000 home child care providers who won recognition in Illinois, and 5,300 mostly immigrant janitors who won recognition in Houston, both through SEIU in 2005; 40,000 child care providers organized by AFSCME and the UAW in Michigan in 2006; and earlier this year, the 4,000 mostly African-American male security officers organized by SEIU in Los Angeles. ${ }^{7}$ The overwhelming majority of these new union members are workers of color, primarily women of color.

Building on these recent successes, we see much potential for organizing gains - either through the NLRB or non-Board strategies - in the occupations where workers of color, women, and women of color predominate and where the union density rates are low: clerical (66 percent female, 5 percent union), service and maintenance (64 percent female, 5 percent union), professional and technical (58 percent female, 6 percent union), health care and social services ( 81 percent female, 7 percent union), and hospitality and food services (56 percent female, 34 percent workers of color, 2 percent union). ${ }^{8}$ But this would mean that unions would have to commit serious resources toward organizing, something that 
all but a handful have thus far failed to do. Still today, unions on both the national and local levels allocate on average just 10 percent of their resources to organizing. ${ }^{9}$

In addition, as Bronfenbrenner has shown in over two decades of research, simply targeting units with majorities of women and workers of color is not enough. The most successful organizing campaigns that are able to overcome intense employer opposition are those that engage in a comprehensive union-building strategy. ${ }^{10}$ In addition to "adequate and appropriate staff and resources" and "strategic targeting and research," among the ten key elements of such a comprehensive strategy are an "active and representative rank-and-file organizing committee," "active participation of member volunteer organizers," and a focus on "issues which resonate in the workplace and community." These latter three elements mean that unions, to be successful in organizing campaigns, must engage in a different model of unionism - one which requires extensive changes in organizational structures and practices in order to create campaigns that speak to the multiple class, racial, and gender injustices workers face at the workplace. While many organizers and scholars argue that the best strategy in organizing a diverse workforce is to take a color- and gender-blind approach, just focusing on the broad class issues that unite workers, Sharon Kurtz reminds us that this is risky. From a strategic standpoint, downplaying or skirting issues of racial or gender justice in an organizing campaign risks undermobilizing workers for whom those issues may resonate, and it also risks alienating external communitybased support and allies, who might be a crucial resource in a hostile organizing campaign. ${ }^{11}$

\section{A MORE REPRESENTATIVE LEADERSHIP}

Engaging in a different model of unionism would also mean developing new rank-and-file leaders who represent a more diverse membership. This issue of developing staff and leadership that represent the changing demo graphics of the workforce and of union members is still one of the most significant challenges facing the labor movement today. It has been more than ten years now since the AFL-ClO created the position of executive vice president and expanded its Executive Council to provide more representation for women and people of color, and Change to Win conscientiously appointed a woman and man of color as its top two officers. But where action is most needed is at the affiliate level: within Internationals and within local unions. For example, according to data from a nationally representative survey of Internationals conducted in 2003, women, workers of color, and immigrants are still severely underrepresented in staff and leadership positions compared to their membership numbers. ${ }^{12}$ And, as the constituency groups have long argued, leadership change must go beyond symbolic and token gestures; women and people of color must be empowered within their 
organizations to represent the interests and concerns of a diverse membership. This issue of leadership representation is even starker in the context of organizing campaigns. There has been some progress in the recruitment and development of lead organizers over the last two decades. From the late 1980 s to the late 1990s, the percentage of female lead organizers increased from 12 percent to 21 percent, while the percentage of lead organizers of color increased from 15 percent to 21 percent. ${ }^{13}$ But that progress has been much too slow, and we know that significant obstacles still remain for organizers of color and women organizers in advancing within their unions. As Daisy Rooks has shown in her interviews with Organizing Institute alumni, the "cowboy mentality" of the white and male occupational culture - where the intense and family-unfriendly working conditions and demands of organizing work are celebrated flourishes in even the most progressive and diverse unions, excluding many women and people of color from the ranks of lead organizers. ${ }^{14}$

Bracketing the ideals of fairness and inclusion for the moment, developing a diverse leadership is an important strategic issue. Simply put, when organizers and lead organizers reflect the workers they are organizing, they win. While the overall win rate in NLRB campaigns for female lead organizers averages 53 percent (compared to 42 percent for men), the average win rate for lead organizers of color is 58 percent (compared to 41 percent for white leads), and for lead women of color organizers is 69 percent (compared to 43 percent). And when the lead organizer is a woman of color in units with over 75 percent women of color, the NLRB election win rate is an astounding 89 percent. ${ }^{15}$ Developing more lead organizers who are female, people of color, and especially women of color, when combined with a comprehensive union-building strategy, is a formula for success. Yet, despite the starkness of these findings, and the great possibilities they offer to the labor movement, neither unions nor scholars studying the labor movement have paid much attention to the critical role women of color, particularly African-American women, have been playing and could be playing in the revival of the U.S. labor movement.

\section{IMPLICATIONS FOR ORGANIZING}

There are at least three implications of this discussion about race and gender in organizing we want to raise here. The first has to do with the need for internal change in unions organizational structures. Institutional change that takes gender seriously requires shedding the "cowboy mentality," and transforming union organizing culture into one that is women-friendly and empowering, one which moves women and women of color organizers up the leadership ranks, instead of burning them out or replicating the corporate glass ceiling. 
Second, unions could be much more strategic about choosing which organizing campaigns to target, and redirecting more resources to organizing workers of color. We are not suggesting that unions stop devoting resources to workplaces where white men predominate (even if they do have the lowest win rates in NLRB elections, and represent the minority of those organized outside the board process). We are suggesting that rather than continue to concentrate the majority of their organizing dollars on campaigns in their core industries where white men predominate, which have neither been chosen strategically nor run strategically, unions devote more resources to organizing workers of color and women of color, especially in the South, by running smarter and much more strategic campaigns overall that would free up already scarce resources

The third and final implication is this: what would it truly mean to have white, black, Latina, and Asian women as members, on staff, and in leadership positions in greater numbers than ever before? What would it look like if women of color were given a real role in the labor movement and an empowered voice in their unions, and their issues and interests were addressed at the bargaining table and on unions' political agendas? As labor prepares for the next election and focuses so much of its efforts on labor law reform, we contend that now more than ever it is important to look back and think about how different the current playing field could have been if unions had not spent all those years thinking the South was not organizable, and writing off red states politically by failing to take notice that there were women of color in light manufacturing, business services, health care, communications, and $\mathrm{IT}$, and especially the public sector (outside of collective bargaining legislation), ready and eager to be organized.

Similarly, we might wonder what kind of labor movement we would have if race - not just immigration - were on the table, or if African Americans were being appointed to leadership positions among staff and officers that reflected their disproportionate representation among organized workers, and in particular among newly organized workers coming into the labor movement.

Most important, we could see how much more effective the U.S. labor movement could be if it were standing up for and speaking out on the issues that mattered for its constituencies of color. Such a labor movement* would have been there front and center, right with the members of the Congressional Black Caucus at the door of the White House, confronting the Bush Administration on the racist nature of the failed response to Hurricane Katrina. And that labor movement would have spoken out with a united voice against the Patriot Act and U.S. foreign policy more generally, knowing that these policies are targeting and affecting workers of color at home and the families of workers of color abroad. 
Diversity is not the enemy of solidarity. We contend that solidarity can, and must, be built among an ever-diversifying labor movement, nation, and world. The labor movement's very survival depends on it.

\section{NOTES}

1. John Schmitt and Ben Zipperer, "Unpublished Analysis of the CEPR Uniform Extracts of the CPS ORG," Center for Economic and Policy Research, 2007. Available online at http:// ceprdata.org.

2. Ibid.

3. Ruth Milkman, LA. Story: Immigrant Workers and the Future of the U.S. Labor Movement (Mew York: Russell Sage, 2006), and Louis Uchitelle, "Labor's Lost; For Blacks, A Dream in Decline," New York Times, October 23, 2005.

4. Kate Bronfenbrenner and Stephanie Luce, "The Changing Nature of Corporate Global Restructuring: The Impact of Production Shifts on Jobs in the US, China, and Around the Globe." Report submitted to the US China Economic and Security Review Commission, October 14, 2004.

5. Steven Pitts, "Bad Jobs: The Overlooked Crisis in the Black Community," New Labor Forum 16 no. 1 (2007): 39-47.

6. Kate Bronfenbrenner, "Organizing Women: The Nature and Process of Union Organizing Efforts Among US Women Workers Since the 1990s," Work and Occupations 32 no.4 (2005): 1-23.

7. Michelle Amber, "SEIU Local 880 Wins Right to Represent 49,000 Illinois Home Child Care Workers," Daily Labor Report 67, p. A-1 3, April 8, 2005; Michelle Amber, "Security Firms in Los Angeles Recognize SEIU for Some 4,000 Security Officers," Daily Labor Report 97, p. A-1 0, May 21, 2007; Susan R. Hobbs, "40,000 Child Care Providers in Michigan Gain UAW, AFSCME Union Representation," Daily Labor Report 241, p. A-9, December 1 5, 2006; Susanne Pagano, "SEIU Janitors in Houston OK First Contract Raising Wages \$2.45 Over Three-Year Term," Daily Labor Report 225, p. A-5, November 22, 2006.

8. Kate Bronfenbrenner, "Organizing Women: The Nature and Process of Union Organizing Efforts Among US Women Workers Since the 1 990s,"Work and Occupations 32 no.4 (2005): 1-23; BLS 2006.

9. Dorian T. Warren, A New Labor Movement for a New Century? The Incorporation of Marginalized Workers in U.S. Unions, Ph.D. Dissertation, Yale University, 2005. 
10. See Kate Bronfenbrenner and Robert Hickey, "Changing to Organize: A National Assessment of Union Strategies." In Ruth Milkman and Kim Voss, eds., Rebuilding Labor: Organizing and Organizers in the New Union Movement (Ithaca: Cornell University Press, 2004) for more detail on the ten key elements of comprehensive union-building strategies.

11. Sharon Kurtz, Workplace Justice: Organizing Multi-Identity Movements (Minneapolis: University of Minnesota Press, 2002).

12. Dorian Warren, Ibid.

13. Kate Bronfenbrenner, "The Role of Union Strategies in NLRB Certification Elections," Industrial and Labor Relations Review 50 (1997): 195-221; Bronfenbrenner, 2005.

14. Daisy Rooks, "The Cowboy Mentality: Organizers and Occupational Commitment in the New Labor Movement," Labor Studies Journal 28, no.3 (2003): 33-62.

15. Bronfenbrenner, 2005. 